167 TORSTEN ANDREASEN

Postdoc

Institut for Kunst- og Kulturvidenskab, Københavns Universitet

\title{
GÆLD, SKYLD OG EN MANGLENDE KRITIK AF VOLDEN
}

Mikkel Thorup

DU SKYLDER! OM MORALSK \& ØKONOMISK GÆLD

Aarhus: Klim, 2016

209 sider

2008 var året, hvor gæld i kraft af et accelererende forløb mellem marts og september i USA for alvor manifesterede sig som generelt strukturelt problem i den bredere bevidsthed. Først måtte investeringsbanken Bear Stearns d. 14. marts med regeringsstøtte lade sig overtage af J.P. Morgan Chase på grund af truende kollaps. D. 6. september blev det annonceret, at de to såkaldte GSE (Government Sponsored Enterprises), Fannie Mae (Fede- ral National Mortgage Association) og Freddie Mac (Federal Home Loan Mortgage Corporation), ville blive underlagt statskontrol. Fannie Mae og Freddie Mac har fra slutningen af 1970'erne og starten af 1980'erne spillet en afgørende rolle for udviklingen af det sekundære marked for boliggæld i form af obligationer, de såkaldte MBS (Mortgage Backed Securities). GSE'ernes opgave er mod gebyr at statsgarantere kvalificerede boliglån, der derved de facto blev omdannet til statsobligationer - en proces, som ligesom al anden låntagning var løbet løbsk op mod 2007. Den sidste og nok mest afgørende begivenhed i dette forløb er investeringsbanken Lehman 
168 KULTUR \& KLASSE $* 128 * 2019$ ANMELDELSER
169 TORSTEN ANDREASEN

GÆLD, SKYLD OG EN MANGLENDE KRITIK AF VOLDEN
Brothers' konkursbegæring d. 15. september og de relaterede redninger af de næste svage led i kæden: investeringsbanken Merill Lynch accepterede at blive overtaget af Bank of America d. 14. september og AIG (American International Group), der havde udstedt forsikringer mod gældens misligholdelse, måtte d. 16. september reddes af New Yorks gren af den føderale nationalbank.

Disse institutionelle sammenbrud udgjorde den ufravigelige manifestation af de foregående års øgede optag af privat boliggæld - særligt såkaldte subprime-lån dvs. lån optaget af mennesker med dårlig kreditværdighed. Siden 1970'erne havde USA taget teten på en dramatisk udvikling i gældens rolle i forhold til de nationale økonomier. Produktionssektoren var ikke længere i stand til at drive den økonomiske ekspansion, hvorfor nye pengestrømme måtte opsøges eller skabes. Ejendomsobligationer og de såkaldte Junk Bonds bidrog til at drive markedet opad fra slutningen af 1970'erne og et godt stykke op i 1980'erne. Efter en kortvarig ekspansion i den amerikanske produktionsøkonomi i starten og midten af 1990'erne, blev væksten primært leveret af oppustede aktie- priser inden for teknologisektoren, hvilket resulterede i den såkaldte dot.com-boble omkring årtusindeskiftet. Herefter tilfaldt rollen som nationaløkonomisk drivkraft atter en gang boliggælden. Tilsvarende fluktuationer gjorde sig gældende i resten af verden med forskellige variationer, men gældens centralitet er generel.

Alt dette har at gøre med opfindelsen af nye finansielle produkter. Tiden, hvor en bank alene kunne udlåne takket være andre kunders indlån, var nu blevet af løst af lånenes forvandling til markedsbaserede investeringsobjekter i form af ikke bare obligationer, men derudover også stadig mere komplekse obligationsformer sammensat af flere boliglån af varierende risikoprofil og tilmed obligationer sammensat af obligationer, sammensat af obligationer.. Bankernes gamle nulsumspil mellem ind- og udlån blev altså afløst af komplekse markedsmekanismer, der takket være stadig mere avancerede og ugennemsigtige MBS-produkter, f.eks. syntetiske CDO (Collateralized Debt Obligations), udgjorde en stadig bedre investering og dermed leverede grundlaget for stadigt større økonomisk ekspansion.
I begyndelsen af det nye årtusind opstod der simpelthen større markedsefterspørgsel efter disse gældsprodukter, end der var udbud, hvorfor det blev vigtigt for udstederne af værdipapirer at producere flere lånere. Det indebar naturligvis en nødvendig sænkning af kreditkravene samt nye låneformer, f.eks. rentevariable lån afdragsfri lån og lån uden udbetaling. Resultatet var, at markedet blev fyldt med det, man efterhånden måtte anerkende som "toxic assets". Systemet kunne fungere så længe boligpriserne steg som følge af de nye lånemidlers tilførelse af billige penge til markedet og den deraf følgende mulighed for konstant refinansiering af lånene på basis af den voksende friværdi men efterhånden som prisstigningerne toppede og stadig flere låntagere måtte opgive tilbagebetaling begyndte de enorme mængder gæld at blive et problem. Systemet viste sig at være en såkaldt "Ponzi scheme", der udelukkende giver afkast, så længe tilførslen af nye indskud fortsætter.

Årsagen til at krisen i 2008 slog igennem i hele det finansielle system fremfor blot i de enkelte insolvente hushold er, at de finansielle institutioner selv var indehavere af enorme mængder problematiske gældsprodukter. Investeringsbankerne ophørte med blot at skabe CDO og CMO (Collateralized Mortgage Obligation) med henblik på umiddelbart videresalg til et sultent marked. De begyndte at ophobe gæld og gældsobligationer i finansielle varelagre for at sikre udbud til den enorme efterspørgsel, men investeringsbankerne betragtede også selv deres varer som en ganske god investering. I starten af 2007 var hele $60 \%$ af USA's bedst ratede $\mathrm{CDO}$-trancher ejet af investeringsbankerne. Og disse besiddelser blev håndteret af såkaldte "conduits" og SIVs (Structured Investment Vehicles) - enheder, der kunne opkøbe og ophobe værdipapirer uden at lade dem figurere i investeringsbankernes officielle regnskaber.

På dette tidspunkt befandt der sig altså i USA gæld for omkring 1,8 trillioner \$ uden for de officielle regnskaber, hvilket blev afgørende i forhold til bankernes sammenbrud. De blev simpelthen overraskede over, hvor meget gæld, de havde akkumuleret. Da markedet i løbet af 2007 og 2008 begyndte at fryse fast, var det ikke længere muligt at værdisætte papirerne, hvorfor de reelt set var værdiløse, 
170 KULTUR \& KLASSE $* 128 * 2019$ ANMELDELSER
171 TORSTEN ANDREASEN

GÆLD, SKYLD OG EN MANGLENDE KRITIK AF VOLDEN ligegyldigt hvor meget f.eks. Lehmans CEO Richard Fuld påstod det modsatte. Og da værdien af Lehman Brothers' beholdninger styrtdykkede, havde de ikke nok pant ("collateral") til sikring af den gæld, de havde optaget hos andre investeringsbanker for via "leveraging" at kunne opkøbe endnu større beholdninger af værdipapirer. Altså begyndte korthuset at falde, hvilket så blev direkte afspejlet i aktieprisens styrtdyk. Lehmans problem var, at aktieprisernes fald gjorde at deres markedsværdi ikke længere kunne dække deres gældsposter hvorfor de reelt set var insolvente.

Markedet frøs fast, bankerne kollapsede, folk måtte gå fra hus og hjem, og den største globale økonomiske recession siden 1929 var en realitet. Krisen var generel fordi den økonomiske vækst siden dot.com-boblen primært havde været baseret på privat boliggæld i en udgave, der altså ikke låner fra andres indlån, men hvor lånet simpelthen skaber penge ud af det blå og hvor pengene forsvinder igen, efterhånden som lånet tilbagebetales. Den økonomiske ekspansion var primært gæld, hvis værdi var baseret på en formodet samlet boligværdi, der i sidste ende viste sig at være ren illusion.
Mikkel Thorups bog Du skylder!-om moralsk og økonomisk gæld udspringer af netop denne situation, hvor verden vågnede op med alvorlige økonomiske tømmermænd efter en fest på gældsbobler. Bankerne måtte reddes af de nationale regeringer, hvorved hovedpinen blev sendt videre til skatteyderne, mens bankdirektørerne som det første gav sig selv rekordstore bonusser. Den økonomiske gælds pludselige manifestation som samfundsmæssig katastrofe blev altså knyttet til moralsk skyld på mindst tre fronter: Det var umoralsk af låntagerne at sætte sig i en situation, hvor de ikke kunne honorere deres forpligtelser; det var umoralsk af bankerne at etablere en gældspraksis, der på trods af tidlige selvlegitimerende diskurser om demokratisering af bolig- og værdipapirsmarkedet ret tydeligt var en udplyndring af allerede økonomisk udsatte; det var umoralsk af staterne at lade bankernes skyld overgå til den almene befolkning via skattefinansiering af redningspakkerne.

Thorups bog beskriver de forestillinger, vi gør os om gæld, ved at kommentere det, han kalder "gældens kulturelle arkiv", med henblik på, at vi alle kan blive bed- re til at dechifrere "den offentlige og private samtale om gæld, vores egne 'spontane' følelser og forestillinger om det at være gældsat" (8). Bogen udgør en form for kulturhistorisk oplysningsprojekt. Selvom Thorup gør rede for gælden som evindeligt civilisatorisk problem udgør det primære fokuspunkt for ham overgangen fra en opsparingslogik til en investeringslogik, hvad man også kunne beskrive som en overgang fra efterkrigstidens produktionsbaserede økonomiske ekspansion til økonomiens finansialisering fra 1970'erne og frem. Thorup er interesseret i disse økonomiske udviklingers kulturelle korrelater i moralske fordringer, hvordan gælden i kraft af disse fordringer sætter sig igennem som disciplinering og subjektivering.

Det er et spørgsmål om gæld som kulturel praksis, hvordan "økonomiske og moralske forhold interagerer i gældsforholdet" (14). I den sammenhæng skelner Thorup mellem moralsk gæld, der er uendelig og altså ikke lader sig fuldt tilbagebetale, og så økonomisk gæld som en endelig størrelse, der forsvinder med tilbagebetalingen. Thorup pointerer dog, hvordan skellet imellem de to fra tid til anden bliver uklart, hvilket for eksem- pel kommer til udtryk i faderen, der på sønnens 21-års fødselsdag præsenterer ham med en "detaljeret regning, der oplistede alle faderens udgifter ved hans søns barndom og ungdom startende med udgiften til fødselslægen" (40).

Disse forskellige forbindelser mellem moralsk og økonomisk skyld og gæld bliver så sporet op igennem et omfattende, om end rent tekstbaseret, kulturelt arkiv a litteratur og filosofi. Platon, Aristoteles, Aquinas, Nietzsche, Foucault, Deleuze, Lazzarato, Hardt/Negri Zizek og Balibar kommer alle på banen, ligesom de litterære referencer omfatter Rabelais, Shakespeare, Swift, Defoe og Ibsen. Der bliver endvidere citeret fra en sær deles bred vifte af den nyere forskningslitteratur. Overgange fra det økonomiske paradigme efter 1971 da USA forlader guld-standarden, beskrives fint i forhold til neoliberalismen som styringsform og subjektiveringsparadigme, ligesom etableringen af privatgælden som grundlag for den økonomiske ekspansion med rette karakteriseres som det, forskellige økonomihistorikere har kaldt "privatiseret keynesianisme".

Det er altså et omfattende projekt, Thorup har sat sig for, og 
172 KULTUR \& KLASSE $* 128 * 2019$

ANMELDELSER
173 TORSTEN ANDREASEN

GÆLD, SKYLD OG EN MANGLENDE KRITIK AF VOLDEN som introduktion til et kulturelt perspektiv på gældsproblematikken før og nu, er bogen ret vellykket. Spørgsmålet er dog, om et sådant kulturelt perspektiv er tilstrækkeligt.

Ved at fokusere på det kulturelle sidder bogen fast $i$ en analyse af forholdet mellem økonomisk fordring og moralsk subjektivering mellem neoliberalistisk ideologi og disciplineringen af det gældsatte subjekt. Ikke ulig Maurizio Lazzaratos vigtige bog La Fabrique de l'homme endetté - Essai sur la condition néolibérale fra 2011, fokuserer Thorup på spørgsmålet om subjektivering. Problemet er bare, at selvom subjektiveringen bestemt er et afgørende aspekt af gældens aktuelle funktion, overser den en økonomisk misere hinsides subjektivering som knyttet til udskamning af skyldneren.

2008 gjorde det i allerhøjeste grad klart, i hvor høj grad gæld er et spørgsmål om fysisk overlevelse, om tag over hovedet, om eksklusion fra den formelle økonomi. Både Lazzarato og Thorup trækker på Foucault, men udover Foucaults redegørelse for den subjektiverende magt, må man ikke overse hans skelnen mellem magt og vold. Hvor subjektivering for Foucault er et spørgsmål om magtens operation som en handling på en handling, en indsnævring af det tilgængelige handlerum, så er gælden også i vid udstrækning et spørgsmål om vold, altså med Foucault en handling på en krop, hvis eventuelle skam således er mindre vigtig.

Thorup påpeger helt rigtigt, at kredit ikke kun skaber forbrugere, men også arbejdere. Men når et enkelt menneske på trods af flere samtidige fuldtidsansættelser ikke kan overleve uden måned for måned at gældsætte sig stadig mere, bliver forholdet mellem skam og gæld på sin vis irrelevant. Og her bliver Thorups samtidsdiagnoser næsten lidt for naive: "I dag er det sådan, at de fleste er 'rige' i den forstand, at de kan låne penge gennem kreditsystemet, men de er 'fattige' i den forstand, at låntagning udleverer os til den moralske vurdering af os som 'gode mennesker"' (112-113). Men hvad med klar diskrimination i adgangen til gæld af forskellig art og på mere eller mindre anstændige betingelser, og hvad med dem, hvis gæld udleverer dem til langt mere livstruende nød end omgivelsernes moralske vurdering?

Thorup påpeger helt rigtigt, at gælden er blevet udbredt i hidtil uset grad, hvorfor han vil opdatere
Deleuzes oprindelige beskrivelse af det forgældede menneske, der også lå til grund for Lazzarato. Deleuze beskrev, hvordan "kapitalismen fortsat har bevaret den ekstreme elendighed for de tre fjerdedele af menneskeheden, der er for fattige til gælden og for mange til at blive spærret inde, og kontrollen vil i fremtiden ikke blot stå overfor opløsningen af grænser, men også en eksplosion i slumkvarterer og ghettoer" (Deleuze citeret 125). Thorup mener, at Deleuze overser at gælden jo netop eksploderer slumkvarterer og ghettoer. Udover at Thorup her synes at negligere Deleuzes (også historiske) skel mellem disciplinering af individet og kontrol af individet, må man understrege, i hvor høj grad verdens slumkvarterer opererer inden for uformelle økonomiske strukturer, hvor gæld uden tvivl er en afgørende faktor, men det drejer sig her om uformel gæld, hvor tilbagebetaling ikke er et moralsk spørgsmål, men et spørgsmål om vold.

Subjektiveringsperspektivet medfører også problemer i analysen af finanssektoren. Thorup skriver tidligt i bogen: "En væsentlig del af udviklingen skyldes formodentlig, at bankerne gik fra at være tilfredse med at kende deres kun- der godt og leve diskret og stabilt til at ville være lige så sexede som finansfolk, reducere deres kunder til algoritmer og tjene hurtige og mange penge på det globale marked" (17). Men den historiske udvikling har ikke rigtig noget at gøre med fordums tilfredshed med det stabile og pludseligt opstået begær efter mere sexede indtjeningsmuligheder. Kapitalismens historiske udvikling determineres af de givne økonomiske betingelser for profit. De "hurtige og mange penge" på det globale marked blev etableret som mulighed via lovgivning, fordi tidligere tiders produktionsbaserede profit ophørte med at være tilgængelig. Den givne økonomiske situation afstedkom politiske tiltag for at muliggøre økonomisk ekspansion via ren cirkulation af værdipapirer. Men bankmandens eller traderens subjektiveringer udsprang af disse historiske processer, subjektiveringerne og deres respektive tilfredshed eller begær var ikke selv drivkraft bag den økonomiske udvikling.

Dette bliver endelig også et problem i forhold til bogens afsluttende beskrivelse af politisk modstand. Thorup beskriver godt, hvordan demokratiet er blevet nominelt, hvordan finanssektoren 
174 KULTUR \& KLASSE * $128 * 2019$

pga. finanskrisen har fået, hvad den tyske litterat Joseph Vogl kalder en suverænitetseffekt, dvs. den instans, der legitimerer ekstraordinære politiske indgreb, som ofte udspringer af uformelle og uigennemsigtige beslutningsprocesser. Finanssektoren bliver ifølge Vogl beskyttet via noget, der minder om permanent undtagelsestilstand. Thorup formulerer det således: "Gældshåndteringen er i mange lande blevet det middel til drastisk reduktion eller omstrukturering af velfærdsstaten til en konkurrencestat, som ingen vestlige politikere nogensinde har kunnet finde flertal for i en demokratisk proces" (146). Men Thorup drager den konklusion, at det sande demokrati er et demokrati uden gæld (153), hvorfor et velfungerende demokrati kan søges genetableret via de forskellige aktivistiske gældseftergivelsestiltag, man har set siden krisen.

Disse tiltag er naturligvis prisværdige, men de formår næppe afmonteringen af de fundamentale kapitalistiske årsager til gælden og dens aktuelle former. Thorup en- der med en gestus i retning af det, der måske burde have været udgangspunktet for analysen, nemlig sammenhængen mellem gæld og vækst: "Gæld er en væsentlig del af grunden til, at politikere og andre taler så meget om vækst. For gæld betales tilbage med renter [...]" (180). Og det er selve sagens kerne: Gæld hænger sammen med vækst, fordi kapitalen er afhængig af sin egen ekspansion. Gæld tager forskud på fremtidig vækst eller, rettere, på fremtidigt arbejde, på den fremtidige produktion af værdi via udbytning og misere. Hvis denne anmeldelse brugte ganske megen plads på indledningsvis at redegøre for den økonomihistoriske baggrund for krisen, er det netop, fordi de forskellige måder, hvorpå økonomien forsøger at sikre egen ekspansion på trods af produktionssektorens svækkelse, udgør de objektive vilkår for både subjektivering og vold. Måske altså både analysen og modstanden bør starte med en kritik af kapitalens nødvendige ekspansion, for at den derigennem kan blive bragt til ophør. 